\title{
Pengaruh Tingkat Pendidikan Dan Motivasi Kerja Terhadap Kinerja Dosen Iain Sultan Amai Gorontalo
}

\author{
Wiwin Koni \\ IAIN Sultan Amai Gorontalo \\ wiwinkoni17@gmail.com
}

\begin{abstract}
ABSTRAK
Penelitian ini bertujuan untuk menguji Pengaruh Tingkat Pendidikan Dan Motivasi Kerja Terhadap Dosen IAIN Sultan Amai Gorontalo .Sumber data yang digunakan dalam penelitian ini adalah data primer dan sekunder yang diperoleh dari hasil kuesioner para responden dan laporan tentang keadaan dosen di bagian akademik dan kepegawaian IAIN Sultan Amai Gorontalo. Teknik sampling yang digunakan adalah random sampling. Sampel dalam penelitian ini 99 responden. Teknik analisis data yang digunakan dalam penelitian ini adalah analisis regresi linier berganda dimana sebelumnya data telah diuji dengan pengujian asumsi klasik meliputi normalitas data, heteroskedastisitas, multikolinieritas dan autokorelasi.

Hasil penelitian menunjukan bahwa tingkat pendidikan tidak berpengaruh signifikan terhadap kinerja dosen. Untuk itu perlu adanya motivasi yang kuat dari pimpinan IAIN Sultan Amai Gorontalo terutama dalam hal pendanaan. Sedangkan variabel motivasi kerja berpengaruh signifikan terhadap kinerja dosen. Oleh karena hal ini sangat penting untuk diapresiasi oleh pengambil kebijakan untuk selalu memberikan dorongan kepada para dosen agar terus meningkatkan kinerjanya lewat motivasi yang kuat.
\end{abstract}

\section{Kata Kunci : Tingkat Pendidikan, Motivasi Kerja, Kinerja Dosen}

\section{PENDAHULUAN}

Dosen sebagai pelaksana Tri Dharma Perguruan tinggi memiliki tanggungjawab yang besar baik kepada dirinya, maupun kepada lembaga dan orang lain. Dengan peran ganda yang dimiliki seorang dosen yakni tidak terbatas hanya sebagai pengajar yang akan memberikan ilmu yang dimilikinya kepada peserta didik namun juga mempunyai peran besar lainnya yang sangat kompleks untuk mencapai tujuan pendidikan. Dengan kompetensi yang dimiliki seorang dosen sesuai dengan undang-undang yang ada di Indonesia dan motivasi kerja untuk memberikan yang terbaik bagi dunia pendidikan khususnya perguruan tinggi sebagai tempat berkarya bagi seorang dosen, maka kinerja dosen yang optimal dapat tercapai.

Pendidikan merupakan faktor utama dalam pembentukan pribadi manusia, pendidikan sangat berperan dalam pembentukan karakter dan pribadi manusia menurut ukuran baik atau 
buruk secara normatif. Pernyataan di atas di dukung oleh Sardiman bahwa pendidikan dan pengajaran adalah satu usaha yang bersifat sadar tujuan, yang dengan sistematis terarah pada perubahan tingkah laku menuju kedewasaan anak didik. ${ }^{1}$ Pernyataan diatas ini sejalan dengan peraturan perundang-undangan tentang guru dan dosen, bahwa guru harus professional, cerdas dan kompetitif. Dalam kaitannya dengan hal ini, telah jelas dinyatakan melalui fungsi dan tujuan pendidikan nasional yang tertuang dalam Undang-Undang No.20 tahun 2003 (SISDIKNAS, Pasal 3) berikut ini:

Pendidikan nasional berfungsi mengembangkan kemampuan dan membentuk watak serta peradaban bangsa yang bermartabat dalam rangka mencerdaskan kehidupan bangsa, bertujuan untuk berkembangnya potensi peserta didik agar menjadimanusia yang beriman dan bertakwa kepada TuhanYang Maha Esa, berakhlak mulia, sehat, berilmu,cakap, kreatif, mandiri, dan menjadi warga Negara yang demokratis serta bertanggungjawab. Melalui sistem pendidikan yang baik diharapkan dapat menghasilkan sumber daya manusia yang berkualitas dan profesional serta mampu menjawab kebutuhan era globalisasi ini. ${ }^{2}$

Sejalan dengan pemikiran diatas, maka untuk meningkatkan kualitas pendidikan, harus disempurnakan terlebih dahulu sistem yang ada yakni komponen-komponen dalam pendidikan yang sangat berpengaruh dalam kualitas pendidikan. Di antara semua komponen, pendidikan pengajar yang disebut dosen di perguruan tinggi merupakan komponen yang sangat vital. Hal ini menurut Sardiman bahwa dalam proses belajar-mengajar atau pendidikan terdapat dua unsur manusia yakni pihak yang belajar dan pihak yang mengajar. ${ }^{3}$

Dalam sektor pendidikan perguruan tinggi, rendahnya kualitas perguruan tinggi yang ada di Indonesia, salah satu penyebabnya adalah rendahnya mutu sumber daya manusia yang ada dalam perguruan tinggi tersebut. Oleh karena itu, seorang dosen wajib meningkatkan profesionalismenya dengan menunjukan kinerja yang baik dalam menjalankan tugas dan tanggungjawabnya yaitu melakukan tridarma perguruan tinggi yang mencakup pendidikan, pengajaran dan pengabdian masyarakat.

IAIN Sultan Amai Gorontalo adalah satu-satunya lembaga perguruan tinggi Islam Negeri di Provinsi Gorontalo. Lembaga Pendidikan Tinggi Islam ini diharapkan menjadi barometer pencerdasan spiritual anak bangsa khususnya bagi masyarakat Gorontalo dan hlm. 42-44.

${ }^{1}$ M. A. Sadirman, Interaksi dan Motivasi Belajar-Mengajar (Jakarta: Raja Grafindo Persada, 2005), 68.

${ }^{2}$ E.Mulyasa, Standar Kompetensi dan Sertifikasi Guru.(Bandung: PT. Remaja Rosdakarya, 2008), hlm.

${ }^{3}$ A. M.Sadirman, Interaksi dan Motivasi Belajar-Mengajar, hlm. 37. 
daerah sekitar untuk menunjang percepatan program unggulan pemerintah Provinsi Gorontalo dalam pengembangan sumber daya manusia. Saat ini IAIN Sultan Amai Gorontalo memiliki dosen berjumlah 131 orang yang terdiri dari 4 (empat Fakultas yaitu Fakultas Tarbiyah dan Keguruan berjumlah 60 orang Fakultas Syariah berjumlah 26 orang Fakultas Ushuludin dan Dakwah berjumlah 29 orang dan Fakultas Ekonomi dan Bisnis Islam berjumlah 26 orang dengan jumlah mahasiswa kurang lebih 4.267 dari ke empat fakultas tersebut. ${ }^{4}$

Berdasarkan hasil wawancara singkat dengan beberapa mahasiswa yang ada dilingkungan IAIN Sultan Amai Gorontalo diketahui bahwa, ada beberapa dosen yang cara pengajarannya tidak variatif atau hanya menggunakan metode ceramah sepanjang perkuliahaan dalam satu semester. Kemudian terbatasnya keterampilan dosen dalam menggunakan media pembelajaran, serta kurangnya tanggung jawab dosen dalam memberikan nilai terhadap hasil belajar mahasiswa. Selanjutnya, keterlambatan dosen dalam mengajar dan tidak memperhatikan mutu materi perkuliahan yang diberikan. Kemudian menurut mereka, penelitian-penelitian yang dilakukan oleh dosen-dosen masih sangat minim. Pada kenyataannya dosen profesional haruslah dosen yang mampu menunjukan kinerja yang tinggi yaitu melakukan Tri Darma perguruan tinggi dalam tugasnya dan mampu berinteraksi dengan orang lain yang berada di lingkungannya, baik dengan sesama dosen, peserta didik maupun dengan organisasi atau institusi yang terkait dengan lembaga pendidikan.

Selain kinerja dosen yang dinilai negatif oleh mahasiswa, namun masih ada juga beberapa penilaian positif terhadap beberapa dosen yang dianggap mampu menjalankan tugas dan tanggung jawabnya sebagai seorang dosen, seperti mengajar dengan baik, melakukan berbagai upaya teknik mengajar yang dapat membuat mahasiswa memahami materi yang diajarkan, tepat waktu dalam mengajar, melakukan berbagai penelitian untuk kemajuan bidang yang ditekuni, serta melakukan pelayanan kepada masyarakat. Hal ini menunjukan bahwa IAIN Sultan Amai Gorontalo memiliki tantangan yang besar dalam memperbaiki kualitas pendidikan yang ada dan mengembangkan sumberdaya manusia didalam perguruan tinggi ini, untuk menjadi Universitas agama Islam terbaik di Indonesia Timur.

Berdasarkan fenomena di atas, maka peneliti tertarik untuk meneliti kinerja dosen dengan mengaitkan tingkat pendidikan, dan motivasi kerja para dosen mengingat peran strategis dosen dalam dunia pendidikan terutama dalam membangun dan memajukan kehidupan bangsa Indonesia.

\footnotetext{
${ }^{4}$ Sumber di ambil dari Kasubag bagian akedemik IAIN Sultan Amai Gorontalo
} 


\section{PEMBAHASAN}

\section{A. Kinerja Dosen}

Kinerja dalam bahasa Indonesia berasal dari kata dasar "kerja" yang diterjemahan dari bahasa Inggris yaitu "performance” yang berarti prestasi kerja, pencapaian kerja, atau hasil kerja. Dalam artian terbatas kinerja sering digunakan untuk mengukur pencapaian kerja seseorang seperti tugas yang diberikan kepada seseorang dalam suatu organisasi atau perusahaan. Kinerja adalah hasil yang diperoleh suatu organisasi baik organisasi tersebut bersifat profitoriented atau non profit oriented. Secara lebih tegas Amstron dan Baron mengatakan kinerja merupakan hasil pekerjaan yang mempuyai hubungan kuat dengan tujuan strategis organisasi, kepuasan konsumen dan memberikan konstribusi ekonomi. ${ }^{6}$ Adapun menurut Bastian kinerja adalah gambaran mengenai tingkat pencapaian pelaksanaan kegiatan, program, kebijaksanaan dalam mewujudkan sasaran, tujuan, misi dan visi organisasi yang tertuang dalam perumusan skema strategis (strategic planning) suatu organisasi. ${ }^{7}$

Wijono menjelaskan bahwa kinerja adalah suatu yang berkenaan dengan apa yang dihasilkan individu melalui tingkah laku dalam pekerjaannya. ${ }^{8}$ Sedangkan Borman dan Schmit dalam Mishra dan Mohapatra, sebagai theaggregated value of the discrete behavioural episodes to the organization that an individual performs over a standard interval of time. ${ }^{9}$ Selanjutnya suatu peryataan mengemukakan bahwa kinerja adalah perilaku. Kinerja adalah suatu yang orang lakukan dan refleksi dari tindakan-tindakan yang orang lakukan. Kinerja bukan konsekuensi atau hasil dari tindakan. Peryataan tersebut dipertegas Cambell dalam Bartram, yaitu:"performance is behaviour. It is something that people do and is reflected in the actions that people take...Performance is not the consequence(s) or result(s) of action. " 10 Berdasarkan definisi-definisi diatas, peneliti menyimpulkan bahwa kinerja adalah tindakan atau perilaku individu dalam melakukan tugas serta tanggung jawabnya dalam suatu

\footnotetext{
${ }^{5}$ Pusat Bahasa Departemen Pendidikan Nasional, Kamus Besar Bahasa Indonesia (Jakarta: PT.Gramedia Pustaka Utama, 2008), hlm. 700.

${ }^{6}$ Michael Armstrong, Performance Management, (Yutran: Tugu Publisher, 2004), hlm. 29.

${ }^{7}$ Indra Bastian,Akuntansi Sektor Publik Edisi Pertama, (Yogyakarta: Badan Penerbit Fakultas UGM, 2001), hlm. 329.

${ }^{8}$ S. Wijono, Psikologi Industri dan Organisasi: Dalam Suatu Bidang Gerak Psikologi Sumber Daya Manusia.(Jakarta: Kencana Prenada Media Group, 2010), hlm. 118.

${ }^{9}$ P.S., Mishra, \& A. K. D. Mohapatra, Relevance of Emotional Intelligence for Effective Job Performance: An Empirical Study. The Journal for Decision MakersVIKALPA, 35,1,53-61. (2010).

${ }^{10} \mathrm{D}$. Bartram, TheGreat Eight Competencies: ACriterioncentric Approach To Validation. Journal of Applied Psychology, 90,6, 1185-1203(2005).
} 
pekerjaan, dan sebagai suatu hasil dari tindakan yang dilakukan dalam rangkamemenuhi tujuan individu maupun organisasi.

Berdasarkan uraian diatas maka dapat disimpulkan bahwa kinerja dosen adalah sebagai suatu tindakan seorang dosen dalam melakukan tugas dan tanggung jawabnya sebagai seorang dosen yaitu melaksanakan tridharma perguruan tinggi yang terdiri dari; pengajaran, penelitian dan pengabdian masyarakat.

\section{B. Dimensi Kinerja}

Suatu peryataan mengenai dimensi kinerja adalah kualitas-kualitas atau wajah suatu pekerjaan atau aktivitas-aktivitas yang terjadi ditempat kerja dengan konduktif terhadap pengukuran. Dimensi pekerjaan menyediakan alat untuk melukiskan keseluruhan cakupan aktivitas di tempat kerja. Sementara itu, tanggung jawab dan kewajiban menyediakan suatu deskripsi depersonalisasi suatu pekerjaan, dimensi kinerja memungkinkan proses deskriptif untukmengambil suatu rute situasional dan personalisasi. Pernyataan tersebut dijelaskan oleh Henderson dalam Wirawan sebagai berikut:

Performance dimensions are those qualities orfeatures of a job or the activities that take place atwork site that are conductive to measurement. They are provide a means for describing the scope of total workplaces activities. While responsibilities and duties provide a depersonalized description of a job, performance dimensions permit the descriptive process to take a situational and personalized route. ${ }^{11}$

Dengan demikian dapat disimpulkan bahwa dimensi kinerja merupakan unsur-unsur yang terdapat dalam suatu pekerjaan yang mampu untuk menunjukan kinerja.Responden penelitian adalah dosen perguruan tinggi yang berstatus pegawai tetap dan dimensi penilaian kinerja didasarkan pada Daftar Penilaian Pelaksanaan Pekerjaan (DP3). Wursanto menjelaskan dalam penilaian kinerja kepada pegawai negeri sipil (PNS) menggunakan sistem DP3 yang menggunakan delapan dimensi kinerja yang terdiri atas: ${ }^{12}$

1. Kesetiaan, dalam arti sempit kesetiaan adalah ketaatan dan pengabdian kepada pancasila, Undang-Undang Dasar 1945, negara dan pemerintah Republik Indonesia. Sementara itu, dalam arti luas, kesetiaan adalah tekad dan kesanggupan menaati,

\footnotetext{
${ }^{11}$ Wirawan, Evaluasi Kinerja Sumber Daya Manusia, (Jakarta: Salemba Empat, 2009), hlm. 65.

${ }^{12}$ G. I. Wursanto, Manajemen Kepegawaian, ed.2.(Yogyakarta: Kanisius, 1989), hlm. 49.
} 
melaksanakan, dan mengamalkan sesuatu dengan disertai penuh kesadaran dan tanggung jawab.

2. Prestasi kerja, adalah hasil yang dicapai oleh seorang pegawai negeri sipil dalam melaksanakan tugas yang dibebankan kepadanya.

3. Tanggung jawab, adalah kesanggupan seseorangpegawai negeri sipil menyelesaikan pekerjaan yangdiserahkan kepadanya.

4. Ketaatan, kesanggupan seorang pegawai negeri sipiluntuk menaati segala peraturan perundangundangandan perturan kedinasan yang berlaku,menaati perintah kedinasan yang diberikan olehatasan yang berwenang, dan kesanggupan untuktidak melanggar larangan yang ditentukan.

5. Kejujuran, yaitu ketulusan hati seseorang pegawainegeri sipil dalam melaksanakan tugas dankemampuan untuk tidak menyalahgunakanwewenang yang diberikan kepadanya.

6. Kerjasama, adalah kemampuan seorang pegawainegeri sipil untuk berkerja sama dengan orang laindalam menyelesaikan suatu tugas yang ditentukansehingga mencapai daya guna dan hasil guna yangsebesar-besarnya.

7. Prakarsa, adalah kemampuan seseorang pegawai negeri sipil untuk mengambil keputusan, langkahlangkah, atau melaksanakan tugas pokok tanpa menunggu perintah.

8. Kepemimpinan, adalah kemampuan seorang pegawai negeri sipil untuk meyakinkan orang lain sehingga dapat dikerahkan secara maksimal untuk melaksanakan tugas pokok.

\section{Faktor Yang Mempengaruhi Kinerja}

Secara umum faktor fisik non fisik sangat mempengaruhi kinerja seseorang. Secara teoritis, Wirawan mengemukakan bahwa ada tiga kelompok variabel yang mempengaruhi perilaku kerja dan kinerja individu yaitu: Variabel individu, variabel organisasi, dan variabel psikologis. ${ }^{13}$ Lebih lanjut ia menjelaskan kinerja merupakan sinergi dari sejumlah faktor dan faktor itu adalah faktor lingkungan internal organisasi, faktor lingkungan eksternal, dan faktor internal pegawai. $^{14}$

1. Faktor internal pegawai, yaitu faktor-faktor dari dalam diri pegawai yang merupakan faktor bawaaan dari lahir dan faktor yang diperoleh ketika ia berkembang. Misalnya:

\footnotetext{
${ }^{13}$ Wirawan, Evaluasi Kinerja Sumber Daya Manusia, (Jakarta: Salemba Empat, 2009), hlm. 77-78.

${ }^{14}$ Ibid, hlm. 80-83.
} 
a.) bakat, merupakan suatu sifat yang sudah sejak lahir dimiliki seorang pegawai, b.) sifat pribadi yaitu setiap seifat yang dimiliki seorang pegawai sebagai seorang individu, c.) keadaan fisik dan kejiwaan yaitu segala yang ada dan melekat dalam individu sebagai suatu tubuh maupun jiwa yang dimiliki seorang pegawai.

2. Faktor yang diperoleh dalam diri individu, misalnya: a.) pengetahuan, yaitu segala sesuatu yang diketahui individu, b.) keterampilan, yaitu segala sesuatu yang dapat dilakukan individu dalam tugasnya sebagai seorang pegawai, c.) etos kerja, yaitu semangat kerja yang menjadi ciri khas dan keyakinan seorang pegawai, d.) pengalaman kerja, yaitu suatu yang pernah dialami atau dikerjakan, e.) motivasi kerja, yaitu suatu kebutuhan atau dorongan yang dimiliki pegawai untuk melakukan pekerjaannya.

Selanjutnya menurut Mangkunegara dalam Soetiksno, faktor yang mempengaruhi kinerja antara lain: ${ }^{15}$

1. Faktor kemampuan, secara umum kemampuan ini dibagi menjadi kemampuan potensi dan kemampuan raliti (knowledge dan skill). Faktor kemampuan ini dapat disebut juga sebagai faktor kompetensi, oleh sebab Knowledge dan skill merupakan karakteristik dari kompetensi.

2. Faktor motivasi, motivasi terbentuk dari sikap pegawai dalam menghadapi situasi kerja.

\section{Tingkat Pendidikan}

Pendidikan diartikan sebagai pendidikan formalyang dicapai atau diperoleh dibangku sekolah.Pendidikan formal yang ditempuh merupakan modal yang amat penting karena dengan pendidikan seseorang mempunyai kemampuan dan dapat dengan mudah mengembangkan diri dalam bidang kerjanya. ${ }^{16}$ Sedangkan pengertian pendidikan menurut Ranupandojo adalah suatu kegiatan untuk meningkatkan pengetahuan umum seseorang termasuk di dalamnya peningkatan penguasaan teori dan keterampilan memutuskan terhadap persoalan-persoalan yang menyangkut kegiatan untuk mencapai tujuan. ${ }^{17}$

Menurut Andrew E. Sikula dalam Mangkunegara tingkat pendidikan adalah suatu proses jangka panjang yang menggunakan prosedur sistematis dan terorganisir, yang mana

\footnotetext{
${ }^{15}$ A. Soetiksno, (2009). Faktor-faktor yang Mempengaruhi Kinerja Dosen Tetap pada Perguruan Tinggi Negeri di Kota Ambon, Jurnal manajemen Akuntansi, VOL. 9.No. 2.

${ }^{16}$ Hani Handoko, ManajemenEdisi Kedua, (Yogyakarta: BPFE UGM, 2003), hlm. 126. hlm. 89.

${ }^{17}$ Heidjrachman Ranupandojo, Manajemen Personalia Edisi Kelima (Yogyakarta: BPFE UGM, 2001),
} 
tenaga kerja manajerial mempelajari pengetahuan konseptual dan teoritis untuk tujuan-tujuan umum. ${ }^{18}$ Sedangkan Hariandja menyatakan bahwa tingkat pendidikan seorang karyawan dapat meningkatkan daya saing perusahaan dan memperbaiki kinerja perusahaan. ${ }^{19}$ Berdasarkan penjelasan di atas maka dapat disimpulkan bahwa pendidikan adalah proses pengubahan sikap dan tata laku seseorang melalui upaya pengajaran dan pelatihan.

\section{E. Motivasi Kerja}

\section{Pengertian Motivasi Kerja}

Motivasi berasal dari kata latin movere, yang berarti bergerak. Dengan demikian, motivasi dapat dijelaskan sebagai proses yang dimulai dengan definisi fisiologis atau psikologis yang menggerakan perilaku atau dorongan yang ditujukan untuk tujuan atau insentif. ${ }^{20}$ Menurut Chaplin motivasi adalah satu variabel penyelang yang digunakan untuk menimbulkan faktor-faktor tertentu didalam organisme yang membangkitkan, mengelola, mempertahankan dan meyalurkan tingkah laku menuju satu sasaran. ${ }^{21}$

Melihat definisi-definisi yang ada, motivasi merupakan suatu konsep yang sangat kompleks dan sulit didefinisikan karena masing-masing ahli memiliki pendapat sendiri berdasarkan aliran masing-masing.Namun menurut peneliti hal penting karena motivasi adalah sesuatu dorongan dalam diri manusia yang menggerakan kehidupannya untuk mencapai suatu yang ingin dicapai atau tujuan hidupnya.

Dengan demikian dapat disimpulkan bahwa, motivasi kerja merupakan suatu kebutuhan dalam diri individu yang merupakan dorongan untuk berbuat aktif dalam melakukan dan mencapai tujuan organisasi diatas tujuan pribadi. Individu yang memiliki motivasikerja yang tinggi dalam dirinya, akan cenderung melakukan tugas pekerjaanya dengan sebaik-baiknya dengan mengutamakan kepentingan organisasi dibandingkan dengan kepentingan dirinya sendiri.

\section{Teori Motivasi Kerja}

Dalam penelitian ini, teori motivasi yang digunakan yaitu teori motivasi McClelland yang merupakan salah satu bagian dalam kelompok teori motivasi diri motivasi isi. Walaupun teori motivasi telah dikembangkan oleh banyak ahli, namun salah satu teori motivasi yaitu

\footnotetext{
${ }^{18}$ Anwar Prabu Mangkunegara, Perencanaan dan Pengembangan Sumber Daya Manusia(Bandung: Refika Aditama, 2003), hlm. 50.

${ }^{19}$ Marihot Tua E. Hariandja, Manajemen Sumber Daya Manusia: Pengadaan, Pengembangan, Pengkompensasian dan Peningkatan Produktivitas Pegawai (Jakarta: Grasindo, 2002), hlm. 169.

${ }^{20}$ Fred Luthans, Perilaku Organisasi Edisi Sepuluh (Yogyakarta: Andi, 2006), hlm. 72.

${ }^{21}$ J.P Chaplin, Kamus Lengkap Psikologi Terj. Kartini Kartono (Jakarta: RajaGrafindo, 2002), hlm. 142.
} 
teori-teori kebutuhan, hamper selalu dihubungkan dengan kinerja seseorang. Pada kesempatan ini, akan dijelaskan teori motivasi isi (content theories of Motivation).

Mullin mengemukakan teori-teori motivasi yang tergolong dalam kelompok teori motivasi isi yaitu: teori kebutuhan berprestasi McClelland. ${ }^{22}$ Teori ini mempuyai peran penting di dalam kaitannya dengan usaha individu untuk mencapai tingkah laku tertentu dalam merealisasikan prestasi kerja atau kinerja. Tiga motif yang dikemukakan McClelland dalam teori ini yaitu: (1). kekuasaan, (2) afiliasi dan (3) berprestasi yang dapat memberi pengaruh terhadap prestasi kerja atau kinerja. Berdasarkan teori ini McClelland tidak melihat kebutuhan individu berdasarkan tingkatan tertentu, tetapi dengan melihat tiga motif yang ada dalam diri individu dalam melakukan suatu pekerjaan.

Selanjutnya, teori motivasi kerja didasarkan pada konsep dasar motivasi menurut Wijono bahwa konsep motivasi telah dipahami atau diterima karena pertama, fenomena tersebut tidak dapat diperhatikan secara langsung. Kedua, motivasi adalah suatu proses hipotesis yang dapat disimpulkan dengan cara memperhatikan tingkah laku seseorang, mengukur perubahan-perubahan dalam prestasi atau mengharapkan penjelasan tentang kebutuhan-kebutuhan dan tujuannya. ${ }^{23}$ Berdasarkan konsep ini maka teori motivasi yang digunakan dalam penelitian ini adalah teori kebutuhan berprestasi McClelland.

\section{Dimensi Motivasi Kerja}

Dimensi motivasi kerja menurut Vandeveer dan Menefee dimensi motivasi kerja dibagi tiga berdasarkan teori McClelland yaitu: ${ }^{24}$

1. The need for achievement atau kebutuhan pencapaian atau berprestasi, merupakan dorongan, mencapai standar-standar berusaha keras untuk berhasil.

2. The need power atau kebutuhan kekuatan atau kekuasaan, merupakan kebutuhan untuk membuat individu lain berperilaku sedemikian rupa sehingga mereka berperilaku yang sebaliknya.

3. The need affiliation atau kebutuhan berafiliasi atau berhubungan, merupakan keinginan untuk menjalin suatu hubungan atar personal yang ramah dan akrab

\footnotetext{
${ }^{22}$ L. J. Mullins, (1994). Management and Organisational Behaviour, 3ed. (Singapore: Longman SingaporePublishers (Ptd), Ltd, 1994), hlm. 382.

${ }^{23}$ S.Wijono, Hubungan Antara Motivasi Kerja dan Personaliti dengan Prestasi Kerja di Sebuah Organisasi.Tesis. Bangi: Universiti Kebangsaan Malaysia 1997.

${ }^{24}$ R.C.Vandeveer.,\&M. L. Menefee Human Behavior in Organizations. (New Jersey: Person Education, Inc, 2006), hlm. 241.
} 
Dengan demikian, dalam penelitian ini, yang menjadi acuan sebagai alat untuk mengukur motivasi kerja individu dengan menggunakan dimensi yang dijelaskan oleh McClelland dalam teori kebutuhan yang mencakup tiga dimensi yaitu prestasi atau pencapaian, kekuasaan dan afiliasi.Teori ini dipilih karena dianggap mampu menjelaskan tindakan seseorang dosen dalam memprediksi kinerja.

\section{Ciri-ciri Motivasi Kerja}

Motivasi kerja berdasarkan teori yang dikemukan oleh David McClelland Luthans menguraikan ciri-ciri individu yang memiliki motivasi kerja yang tinggi yaitu: ${ }^{25}$

a. Kebutuhan untuk berprestasi

b. Kebutuan untuk kekuasan

c. Kebutuhan akan afliasi

Berdasarkan uraian diatas, dapat disimpulkan bahwa individu yang memiliki ciri motivasi kerja yang kuat dalam dirinya dalam melakukan tugas dan tanggung jawabnya khususnya bila dikaitkan dalam hubungan dengan kapasitas sebagai seorang pengajar atau dosen.Akan tetapi berdasarkan kenyataan yang terjadi setiap orang belum mampu memiliki motivasi kerja yang kuat dengan memenuhi setiap aspek dalam teori ini. Hal ini jelas untuk dipahami, berdasarkan penjelasan McClelland bahwa setiap orang akan memiliki ketiga kebutuhan ini di dalam dirinya, tetapi terkait dengan pekerjaan yang di lakukan, setiap orang akan cenderung kombinasi kebutuhan yang lebih kuat dan salah satu kebutuhan yang cenderung lemah. Akan tetapi secara keseluruhan, ciri-ciri motivasi kerja berdasarkan teori McClelland ini sangat tepat digunakan dalam penelitian ini, oleh karena ciri-ciri ini mampu menjelaskan kebutuhan seorang dosen di perguruan tinggi.

\section{F. Hubungan Antar Variabel}

\section{Pengaruh Tingkat Pendidikan Terhadap Kinerja Dosen}

Pendidikan formal yang ditempuh merupakan modal yang amat penting karena dengan pendidikan seseorang mempuyai kemampuan dan dapat dengan mudah mengembangkan diri dalam bidang kerjanya. ${ }^{26}$ Sedangkan pengertian pendidikan menurut Ranupandojo adalah suatu kegiatan untuk meningkatkan pengetahuan umum seseorang termasuk di dalamnya peningkatan penguasaan teori dan keterampilan memutuskan terhadap persoalan yang menyangkut untuk mencapai tujuantermasuk di dalamnya peningkatan penguasaan teoridan

\footnotetext{
${ }^{25}$ Fred Luthans, Perilaku Organisasi Edisi Sepuluh (Yogyakarta: Andi, 2006), hlm. 173.

${ }^{26}$ Hani Handoko, ManajemenEdisi Kedua, (Yogyakarta: BPFE UGM, 2003), hlm. 126.
} 
keterampilan memutuskan terhadap persoalanpersoalanyang menyangkut kegiatan untuk mencapaitujuan. ${ }^{27}$

Menurut Andrew E. Sikula dalam Mangkunegara tingkat pendidikan adalahsuatu proses jangka panjang yang menggunakanprosedur sistematis dan terorganisir, yang mana tenagakerja manajerial mempelajari pengetahuan konseptualdan teoritis untuk tujuan-tujuan umum. ${ }^{28}$ Sedangkan Hariandja menyatakan bahwatingkat pendidikan seorang karyawan dapat meningkatkan daya saing perusahaan dan memperbaiki kinerja perusahaan. ${ }^{29}$

Dari uraian di atas dapat disimpulkan bahwa pendidikan adalah suatu kegiatan atau prosesuntuk memperoleh pengetahuan dan ketrampilandalammengembangkan dan meningkatkan kemampuan seseorang. Hasil penelitian Tanjung menunjukan bahwa tingkat pendidikan berpengaruh positif dan signifikan terhadap kinerja karyawan.. ${ }^{30} \mathrm{Hal}$ yang sama juga dapat dilihat dari hasil penelitian Purwanto(1984) (Turin, 2003), yang menyatakan bahwa kualitas pendidikan dan pengajaran yang dilakukan dosen dipengaruhi tingkat pendidikannya. Supaya dapat melaksanakan tugas secara optimal dan maksimal maka tingkat pendidikan dosen harus ditingkatkan.

Berdasarkan hasil penelitian-penelitian di atas maka dapat disimpulkan adanya pengaruh tingkat pendidikan terhadap kinerja dosen.

H:1 Adanya pengaruh positif tingkat pendidikan terhadap kinerja dosen.

\section{Pengaruh Motivasi Kerja Terhadap Kinerja Dosen}

Menurut Luthans motivasi berasal dari kata latinmovere, yang berarti bergerak. Dengan demikian, motivasi dapat dijelaskan sebagai proses yang dimulai dengan definisi fisiologis atau psikologis yang menggerakan perilaku atau dorongan yang ditujukan untuk tujuan atau insentif. ${ }^{31}$ Sementara itu, As'ad mengemukakan bahwa motif sering diartikan sebagai dorongan. Dorongan atau tenaga tersebut menggerakan jiwa dan jasmani untuk berbuat. ${ }^{32}$ Sejalan dengan As'ad, Gibson, Ivancevich dan Donnelly yang merumuskan motivasi sebagai konsep yang digunakan untuk menggambarkan dorongan-dorongan yang

\footnotetext{
hlm. 89 .

${ }^{28}$ Anwar Prabu Mangkunegara, Perencanaan dan Pengembangan Sumber Daya Manusia(Bandung: Refika Aditama, 2003), hlm. 50.

${ }^{29}$ Marihot Tua E. Hariandja, Manajemen Sumber Daya Manusia: Pengadaan, Pengembangan, Pengkompensasian dan Peningkatan Produktivitas Pegawai (Jakarta: Grasindo, 2002), hlm. 169.

${ }^{30}$ R.Tanjung, Pengaruh Tingkat Pendidikan dan Insentif terhadap Kinerja Karyawan pada PTGaruda Plaza Hotel Medan.Skripsi.Medan: Universitas Sumatera Utara. 2011

${ }^{31}$ Fred Luthans, Perilaku Organisasi Edisi Sepuluh (Yogyakarta: Andi, 2006), hlm. 173.

${ }^{32}$ M. As'ad, Psikologi Industri. (Yogyakarta: Liberty, 2004), hlm. 79.
}

${ }^{27}$ Heidjrachman Ranupandojo, Manajemen Personalia Edisi Kelima (Yogyakarta: BPFE UGM, 2001), 
timbul pada atau didalam seorang individu yang menggerakan dan mengarahkan perilaku. ${ }^{33} \mathrm{Hal}$ ini juga sependapat dengan sebuah pernyataan yang menjelaskan bahwa motivasi adalah keadaan dalam diri individu yang menyebabkan seseorang melakukan perilaku-perilaku tertentu atau khusus. Peryataan ini ditegaskan oleh Spector yaitu motivation is generally definedas an internal state that induces a person to engage inparticular behaviors. $^{34}$ Menurut Robbins dan Judge,motivasi sebagai proses yang menjelaskan intensitas, arah dan ketekunan seorang individu untukmencapai tujuannya. ${ }^{35}$

Munandar menyimpulkan motivasi kerja sebagai suatu proses dimana kebutuhankebutuhan mendorong seseorang untuk melakukan serangkaian kegiatan yang mengarah ke tercapainya tujua tertentu. ${ }^{36}$ Sejalan As'ad mengemukakan bahwa motivasi kerja seseorang ikut menentukan besar kecilnya prestasinya.Sehingga motivasi kerja merupakan bagian yang penting dari kinerja.Sementaraitu Kartono mengemukakan bahwa motivasi kerja tidak hanya berwujud kebutuhan ekonomis saja tetapi dapat juga dalam bentuk kebutuhan psikis untuk aktif berbuat.Dengan demikian dapat disimpulkan bahwa,motivasi kerja merupakan suatu kebutuhan dalam diri individu yang merupakan dorongan untuk berbuat aktifdalam melakukan dan mencapai tujuan organisasidiatas tujuan pribadi.

Berdasarkan teori motivasi dan penelitian-penelitian diatas maka dapat disimpulkan bahwa ada pengaruh motivasi terhadap kinerja dosen.

H:2di duga ada pengaruh positif motivasi terhadap kinerja dosen.

\section{G. Deskripsi Data Responden Penelitian}

Gambaran tentang 99 responden yang memenuhi syarat sebagai data penelitian, berdasarkan jenis kelamin, umur, tingkat pendidikan dan lama mengajar pada Institut Agama Islam Negeri Sultan Amai Gorontalo adalah sebagai berikut:

1. Sebaran Responden Berdasarkan Jenis Kelamin

Gambaran tentang sebaran responden berdasarkan jenis kelamin adalah sebagaimana terlihat dalam tabel berikut ini:

\section{Tabel. 3}

\section{Sebaran Responden Berdasarkan Jenis Kelamin}

\footnotetext{
${ }^{33}$ Ivancevich Gibson., \& Donnely.Organizations, 8ed. (Jakarta: Binarupa Aksara, 1996), hlm. 307.

${ }^{34} \mathrm{P}$. E Spector, Industrial and Organizational Psychology (Research and Practice). (USA: John Wiley \& Sons, INC, 2007), hlm. 200.

${ }^{35}$ S.P. Robbins., \& A. T. Judge, Perilaku Organisasi, ed.12. (Jakarta: Salemba Empat, 2008), hlm. 77.

${ }^{36}$ A. S. Munandar, Psikologi Industri dan organisasi.(Jakarta: IU-Press, 2006), hlm. 93.
} 


\begin{tabular}{|c|c|c|c|}
\hline No & Jenis Kelamin & Frekuensi & Persentase \\
\hline 1 & Laki-laki & 48 & $48,5 \%$ \\
\hline 2 & Perempuan & 51 & $51,5 \%$ \\
\hline \multicolumn{2}{|c|}{ Total } & 99 & 100 \\
\hline
\end{tabular}

\section{Sumber: Data primer diolah}

Dari data di atas diketahui bahwa dosen berjenis kelamin laki-laki berjumlah 48 orang atau 48,5\%. Sedangkan dosen berjenis kelamin perempuan berjumlah 51 orang atau 51,5\%. Hal ini menunjukan bahwa dosen yang mengajar pada IAIN Sultan Amai Gorontalo di dominasi oleh dosen yang berjenis kelamin perempuan.

2. Sebaran Responden Berdasarkan Usia

Gambaran tentang sebaran responden berdasarkan usia mereka dapat dilihat pada tabel berikut:

Tabel . 4

Sebaran Responden Berdasarkan Usia

\begin{tabular}{|c|c|c|c|}
\hline No & Usia & Frekuensi & Persentase \\
\hline 1 & $28-35$ & 20 & $20,2 \%$ \\
\hline 2 & $36-45$ & 65 & $65,7 \%$ \\
\hline 3 & $46-51$ & 14 & $14,1 \%$ \\
\hline \multicolumn{2}{|c|}{ Total } & 99 & 100 \\
\hline
\end{tabular}

\section{Sumber: Data primer diolah}

Dari data di atas diketahui bahwa dosen yang berumur 28 s/d 35 tahun berjumlah 20 orang (20,2\%), dosen yang berumur 36 s/d 45 tahun berjumlah 65 orang $(65,7 \%)$, sedangkan dosen yang berumur 46 s/d 51 tahun berjumlah 14 orang $(14,1 \%)$. Hal ini menunjukan bahwa dosen yang mengajar pada IAIN Sultan Amai Gorontalo di dominasi oleh dosen yang berumur 36 s/d 45 tahun.

3. Sebaran Responden Berdasarkan Tingkat Pendidikan

Gambaran tentang sebaran responden berdasarkan tingkat pendidikan dapat dilihat pada tabel berikut: 
Tabel. 5

Sebaran Responden Berdasarkan Tingkat Pendidikan

\begin{tabular}{|c|c|c|c|}
\hline No & Tingkat Pendidikan & Frekuensi & Persentase \\
\hline 1 & S2 & 46 & $46,5 \%$ \\
\hline 2 & S3 & 53 & $53,5 \%$ \\
\hline \multicolumn{2}{|c|}{ Total } & 99 & 100 \\
\hline
\end{tabular}

\section{Sumber: Data primer diolah}

Dari data di atas diketahui bahwa dosen yang berpendidikan S2 berjumlah 46 orang $(46,5 \%)$ sedangkan responden yang berpendidikan S3 berjumlah 53 orang $(53,5 \%)$. Hal ini menunjukan bahwa dosen yang mengajar pada IAIN Sultan Amai Gorontalo di dominasi oleh dosen yang memiliki tingkat pendidikan S3.

4. Sebaran Responden Berdasarkan Lama Mengajar

Gambaran tentang sebaran responden berdasarkan lama mengajar dapat dilihat pada tabel berikut:

\section{Tabel 6}

Sebaran Responden Berdasarkan Lama Mengajar

\begin{tabular}{|c|c|c|c|}
\hline No & Lama Mengajar (tahun) & Frekuensi & Persentase \\
\hline 1 & $1-5$ & 6 & $6,1 \%$ \\
\hline 2 & $6-10$ & 24 & $24,1 \%$ \\
\hline 3 & $11-15$ & 33 & $33,3 \%$ \\
\hline 4 & $16-20$ & 19 & $19,2 \%$ \\
\hline 5 & $21-25$ & 9 & $9,1 \%$ \\
\hline 6 & $26-30$ & 7 & $7,1 \%$ \\
\hline 7 & $>31$ & 1 & $1,1 \%$ \\
\hline \multicolumn{2}{|c|}{ Total } & 99 & 100 \\
\hline
\end{tabular}

\section{Sumber: Data primer diolah}

Dari data di atas diketahui bahwa dosen yang memiliki lama mengajar $1 \mathrm{~s} / \mathrm{d} 5$ tahun berjumlah 6 orang $(6,1 \%)$, dosen yang memiliki lama mengajar 6 s/d 10 tahun berjumlah 24 orang $(24,1 \%)$, dosen yang memiliki lama mengajar 11 s/d 15 tahun berjumlah 33 orang (33,3\%), dosen yang memiliki lama mengajar 16 s/d 20 tahun berjumlah 19 orang $(19,2 \%)$, dosen yang memiliki lama mengajar $21 \mathrm{~s} / \mathrm{d} 25$ tahun berjumlah 9 orang $(9,1 \%)$, dosen yang memiliki lama mengajar 26 s/d 30 tahun berjumlah 7 orang $(7,1 \%)$, dan dosen yang memiliki lama mengajar diatas 31 tahun berjumlah 1 orang $(1,1 \%)$. Hal ini menunjukan bahwa dosen yang mengajar pada IAIN Sultan Amai Gorontanlo di dominasi oleh dosen yang memiliki pengalaman mengajar $11 \mathrm{~s} / \mathrm{d} 15$ tahun. 
A. Deskripsi Variabel Penelitian

\section{Kinerja Dosen}

Kinerja adalah suatu keberhasilan dari suatu individu dalam suatu tugas dalam pekerjaannya. Untuk melihat profil kinerja dari para responden yakni dosen tetap di IAIN Sultan Amai Gorontalo, maka diajukan 14 pertanyaan kepada 99 orang dosen yang menjadi responden dalam penelitian ini. Tabel 7 merupakan data statistik deskriptif tentang pertanyaan-pertanyaan untuk mengukur kinerja dosen di IAIN Sultan Amai Gorontalo.

Tabel 7.

\section{Statistik deskriptif Rata-Rata Variable Penelitian Kinerja Dosen (n=99)}

\begin{tabular}{|c|c|c|c|c|c|}
\hline No & Indikator Variabel Kinerja Dosen & Min & Max & Mean & $\begin{array}{c}\text { Stand. } \\
\text { Dev }\end{array}$ \\
\hline 1. & $\begin{array}{l}\text { Mengutamakan kepentingan } \\
\text { universitas/Fakultas } \\
\text { dibandingkan kepentingan sendiri }\end{array}$ & 2 & 5 & 4,24 & 0,701 \\
\hline 2. & $\begin{array}{l}\text { Mempunyai keterampilan yang baik dan } \\
\text { pengalaman yang luas } \\
\text { mengenai pembelajaran }\end{array}$ & 3 & 5 & 4,71 & 0,500 \\
\hline 3. & $\begin{array}{l}\text { Menyelesaikan tugas dengan sebaik- } \\
\text { baiknyadan tepat pada waktunya }\end{array}$ & 3 & 5 & 4,53 & 0,644 \\
\hline 4. & $\begin{array}{l}\text { Bertanggung jawab atas setiap keputusan } \\
\text { yang diambil dan } \\
\text { tindakan yang dilakukan }\end{array}$ & 3 & 5 & 4,47 & 0,578 \\
\hline 5. & $\begin{array}{l}\text { Menaati peraturan perundang-undangan dan } \\
\text { peraturan universitas/fakultas yang berlaku }\end{array}$ & 2 & 5 & 4,32 & 0,667 \\
\hline 6. & $\begin{array}{l}\text { Memberikan pelayanan dan pengajaran yang } \\
\text { lebih baik kepada } \\
\text { Mahasiswa }\end{array}$ & 4 & 5 & 4,65 & 0,480 \\
\hline 7. & $\begin{array}{l}\text { Melaksanakan tugas dengan iklas tidak } \\
\text { menyalah gunakan wewenang }\end{array}$ & 4 & 5 & 4,43 & 0,498 \\
\hline 8. & $\begin{array}{l}\text { Melaporkan hasil kerja kepada pimpinan } \\
\text { fakultas/Universitas } \\
\text { menurut keadaan yang sebenarnya }\end{array}$ & 3 & 5 & 4,48 & 0,660 \\
\hline 9. & $\begin{array}{l}\text { Menghargai pendapat orang lain, dan } \\
\text { menerima keputusan yang diambil secara sah } \\
\text { walapun tidak sependapat }\end{array}$ & 1 & 5 & 4,12 & 0,972 \\
\hline 10. & $\begin{array}{l}\text { Mampu berkerja sama dengan orang lain } \\
\text { menurut waktu dan bidang } \\
\text { tugas yang ditentukan }\end{array}$ & 3 & 5 & 4,23 & 0,550 \\
\hline 11. & $\begin{array}{l}\text { Berusaha memberikan saran/ pendapat baik } \\
\text { yang berhubungan } \\
\text { dengan pelaksanaan tugas mengajar }\end{array}$ & 3 & 5 & 4,36 & 0,677 \\
\hline 12. & $\begin{array}{l}\text { Berinisiatif dalam menciptakan pola } \\
\text { mengajar baru yang lebih efektif }\end{array}$ & 3 & 5 & 4,28 & 0,732 \\
\hline 13. & Bertindak tegas dan tidak memihak & 3 & 5 & 4,37 & 0,564 \\
\hline 14. & $\begin{array}{l}\text { Berusaha memberikan motivasi dan dukungan } \\
\text { bagi orang lain }\end{array}$ & 3 & 5 & 4,32 & 0,550 \\
\hline & Rata-rata & 3 & 5 & 4,49 & 0,542 \\
\hline
\end{tabular}

Sumber: Lampiran 4 Hasil Pengolahan Data SPSS, 2016 
Tabel 7 di atas menunjukan bahwa rata-rata kinerja dosen IAIN Sultan Amai Gorontalo yaitu 4.49 yang terletak pada interval 4,12 - 5,00. Hal ini berarti bahwa responden sangat setuju atau memiliki kinerja yang sangat baik. Standar deviasi 0,542 menunjukan dispersi untuk variabel kinerja relatif tinggi. Dalam pengukuran konsep kinereja dosen terdapat empat indikator yang menunjukan bahwa responden cenderung memiliki kinerja yang baik. Artinya, dengan memiliki kinerja yang baik para responden mampu memberikan pembelajaran dan pengajaran yang lebih baik kepada para mahasiswa. Kinerja yang baik yang dimiliki oleh para dosen dapat meningkatkan proses pembelajaran. Selalu berinisiatif dalam menciptakan pola mengajar baru yang lebih efektif, hal ini dilakukan agar para mahasiswa lebih aktif dalam situasi belajar dan tidak mengalami kejenuhan. Bertindak tegas dan tidak memihak, tindakan yang adil mampu menimbulkan rasa persamaan dan kedekatan bagi para mahasiswa sehingga semua mahasiswa merasa nyaman dan sama-sama merasa dihargai.

\section{Motivasi Kerja}

Motivasi adalah suatu dorongan dalam diri manusia yang menggerakan kehidupannya untuk mencapai suatu yang ingin dicapai atau tujuan hidupnya. Ada tiga motif dalam variabel motivasi yakni motif afiliasi, kekuasaan, dan berprestasi. Untuk mengetahui motivasi dari para responden dalam penelitian ini maka diajukan 7 (tujuh) pertanyaan kepada masing-masing responden melalui kuesioner yang dibagikan kepada setiap dosen tetap di IAIN Sultan Amai Gorontalo.

Tabel 8.

Statistik deskriptif Rata-Rata Variable Motivasi Kerja (n=99)

\begin{tabular}{|c|l|c|c|c|c|}
\hline No & \multicolumn{1}{|c|}{ Indikator Variabel Motivasi Kerja } & Min & Max & Mean & $\begin{array}{c}\text { Stand. } \\
\text { Dev }\end{array}$ \\
\hline 1. & Memiliki rasa empati terhadap orang lain & 2 & 5 & 3,80 & 0,903 \\
\hline 2. & Selalu ingin memimpin kelompok & 1 & 5 & 3,35 & 1,072 \\
\hline 3. & Sering mengatur orang lain & 1 & 5 & 3,07 & 1,090 \\
\hline 4. & $\begin{array}{l}\text { Selalu berusaha mendapatkan jabatan yang } \\
\text { baik }\end{array}$ & 1 & 5 & 3,05 & 1,304 \\
\hline 5. & Sering bersikap jujur dengan tegas & 2 & 5 & 4,26 & 0,723 \\
\hline 6. & Senang berkerja dalam kelompok & 2 & 5 & 4,00 & 0,571 \\
\hline 7. & Cenderung bosan pekerjaan yang rutin & 1 & 4 & 2,96 & 1,068 \\
\hline & \multicolumn{1}{|c|}{ Rata-rata } & 2 & 5 & 3,58 & 0,624 \\
\hline
\end{tabular}

Sumber: Lampiran 5 Hasil Pengolahan Data SPSS, 2016

Tabel 8 menunjukan bahwa rata-rata motivasi kerja responden adalah 3,58 yang berada pada interval 2,29-4,26. Hal ini menunjukan bahwa rata-rata respon setuju terhadap motivasi kerja atau motivasi kerja dosen IAIN Sultan Amai Gorontalo masih dapat dikatakan 
baik. Standar deviasi 0.542 menunjukan disperse netral atau nilai yang rata-rata. Dengan demikian hasil menunjukan bahwa jawaban responden menyebar ke dalam lima kategori. Terdapat tiga indikator dalam pengukuran konsep motivasi kerja, dengan nilai rata-rata tertinggi dan tergolong dalam kategori sangat setuju. Pertama, dengan rata-rata nilai sebesar 3,80 menunjukan bahwa responden memiliki rasa empati terhadap orang lain. Pertanyaan kedua, memiliki rata-rata nilai sebesar 3,35 artinya responden selalu ingin memimpin kelompok masih berada pada kategori netral. Ketiga, memiliki nilai rata-rata 3,07 para responden ketika ditanyakan dalam mengatur orang lain terutama mahasiswa berada dalam kategori netral artinya, ketika ada sesuatu hal yang memerlukan untuk mengatur orang lain, maka hal itu dilakukan. Keempat, memiliki nilai rata-rata 3,05 bersikap jujur dan tegas dalam bertindak. Ketiga hal ini merupinya akan indikator yang memperlihatkan bahwa responden memiliki motivasi kerja yang baik. Responden dalam penelitian ini bersikap biasa saja atau kurang termotivasi dalam upaya untuk memperoleh jabatan yang baik. Hal ini diperkuat dengan indikator yang menunjukan rata-rata jawaban terendah yaitu sebesar 2,96 dimana sebagian besar responden memiliki sikap yang netral bahkan cenderung kurang berupaya dalam menghadapi pekerjaan yang bersifat rutin.

Tabel 10.

\section{Ringkasan Hasil Uji Hipotesis Secara Parsial}

\begin{tabular}{|c|l|c|c|}
\hline No & Variabel Independen & Hipotesis & Hasil Analisis \\
\hline 1 & Pendidikan & Berpengaruh Signifikan & Tidak Signifikan \\
\hline 2 & Motivasi Kerja & Berpengaruh Signifikan & Berpengaruh Signifikan \\
\hline
\end{tabular}

Dari hasil uji hipotesis di atas, ditemukan bahwa dari 2 (dua) variabel yang diprediksi mempengaruhi kinerja dosen IAIN Sultan Amai Gorontalo, ternyata hanya variabel motivasi kerja yang berpengaruh signifikan dan positif. Sedangkan variabel pendidikan tidak berpengaruh tetapi positif berhubungan dengan kinerja dosen. Berikut rincian penjelasan dari variabel yang berpengaruh signifikan dan variabel yang tidak berpengaruh signifikan :

1. Variabel Pendidikan

Variabel tingkat pendidikan dosen IAIN Sultan Amai Gorontalo tidak berpengaruh signifikan terhadap kinerja dosen. Artinya dosen tidak menganggap bahwa tingkat pendidikan yang selama ini disandangnya tidak terkait dengan kinerja dosen pada Universitas tersebut. Jika dilihat dari nilai koefisien regresi dari variabel 0.008872 , tampak nilainnya positif. 
Artinya jika dosen merasakan bahwa tingkat pendidikan akan meningkatkan kinerjanya sebagai dosen, maka ia akan cenderung untuk melanjutkan tingkat pendidikan ke jenjang yang lebih tinggi. Hal ini sesuai dengan pendapat Andrew E. Sikula dan Hariandja menyatakan bahwa tingkat pendidikan seorang karyawan dapat meningkatkan daya saing perusahaan dan memperbaiki kinerja perusahaan. ${ }^{37}$ Ketika jenjang pendidikan seseorang rendah, maka ia cenderung memiliki persepsi yang sempit terhadap suatu masalah. Demikian juga sikapnya cenderung sebatas parsepsi ia miliki. Hal ini berlaku pula bagi kondisi dosen yang menjadi obyek penelitian. Semakin rendah jenjang pendidikan dosen ia akan cenderung memiliki persepsi sempit terhadap peningkatan kinerja dosen. Ia tidak berpikir tentang pengembangan diri dalam upaya pengajaran dan keterampilan untuk pengembangan Universitas dimana ia bekerja. Sebaliknya, semakin tinggi jenjang pendidikan seorang dosen, maka ia semakin memiliki persepsi dan sikap yang berdeminsi luas. Setiap pengajaran dan keterampilan yang ia miliki selalu berorientasi untuk peningkatan kinerja, dan hal ini akan berdampak luas terhadap masa depan Universitas.

Dalam arti semakin tinggi jenjang pendidikan seseorang, maka akan semakin memiliki pola berpikir lebih rasional. Jika seorang dosen memiliki jenjang pendidikan lebih tinggi maka ia meningkatkan kinerjanya.Berdasarkan penjelasan di atas maka dapat disimpulkan bahwa pendidikan adalah proses pengubahan sikap dan tata laku seseorang melalui upaya pengajaran dan pelatihan.

\section{Variabel Motivasi Kerja}

Variabel motivasi kerja dosen IAIN Sultan Amai Gorontalo berpengaruh signifikan terhadap kinerja dosen. Variabel ini memiliki nilai koefisien regresi sebesar 0.225778 , dan positif. Artinya seorang dosen yang memiliki motivasi kerja yang tinggi cenderung termotivasi untuk dapat berprestasi baik dalam kegiatan belajar mengajar, penelitian dan pengabdian pada masyarakat. Motivasi kerja merupakan suatu kebutuhan dalam diri individu yang merupakan dorongan untuk berbuat aktif dalam melakukan dan mencapai tujuan organisasi diatas tujuan pribadi. Individu yang memiliki motivasi kerja yang tinggi dalam dirinya, akan cenderung melakukan tugas pekerjaanya dengan sebaik-baiknya dengan mengutamakan kepentingan organisasi dibandingkan dengan kepentingan dirinya sendiri.

\footnotetext{
${ }^{37}$ Marihot Tua E. Hariandja, Manajemen Sumber Daya Manusia: Pengadaan, Pengembangan, Pengkompensasian dan Peningkatan Produktivitas Pegawai (Jakarta: Grasindo, 2002), hlm. 169.
} 


\section{PENUTUP}

Dari hasil penelitian dan pembahasan di atas, maka dapat ditarik kesimpulan sebagai berikut:

1. Secara simultan, kedua variabel yaitu tingkat pendidikan dan motivasi kerja berpengaruh signifikan terhadap kinerja dosen IAIN Sultan Amai Gorontalo $(0.001312<0,05)$.

2. Secara parsial, kedua variabel tersebut hasilnya adalah sebagai berikut:

a. Variabel pendidikan $(0.7245>0,05)$ tidak berpengaruh signifikan, namun variabel ini berkorelasi positif (0.008872) dengan kinerja dosen IAIN Sultan Amai Gorontalo.

b. Variabel motivasi kerja $(0.0003<0,05)$ berpengaruh signifikan dan positif (0.225778) terhadap kinerja dosen IAIN Sultan Amai Gorontalo.

Berdasarkan kesimpulan di atas, maka implikasi hasil penelitian ini adalah sebagai berikut:

1. Untuk membangun kinerja dosen pentingnya keseriusan pemimpin untuk selalu mendorong agar para dosen-dosen di IAIN Sultan Amai Gorontalo melanjutkan studi pendidikan ke jenjang yang lebih tinggi karena mengingat masih banyak juga dosen yang memiliki tingkat pendidikan S2.

2. Untuk meningkatkan kinerja dosen maka para pemimpin IAIN Sultan Amai Gorontalo penting memberikan motivasi kerja yang tinggi lewat program-program peningkatan mutu, pelayanan terutama memberikan penghargaan (insentif) kepada dosen-dosen yang berprestasi. 


\section{DAFTAR PUSTAKA}

Arikunto Suharsimi, Prosedur Penelitian Suatu Pendekatan Praktek Edisi Revisi V Jakarta: PT.Rineka Cipta, 2002.

Armstrong Michael, Performance Management, (Yutran: Tugu Publisher, 2004)

As'ad M., Psikologi Industri. Yogyakarta: Liberty, 2004.

Bartram D, The Great Eight Competencies: A Criterioncentric Approach To Validation. Journal of Applied Psychology, 90,6, 1185-1203 2005.

Bastian Indra, Akuntansi Sektor Publik Edisi Pertama,Yogyakarta: Badan Penerbit Fakultas UGM, 2001.

Chaplin J.P, Kamus Lengkap Psikologi Terj. Kartini Kartono Jakarta: Raja Grafindo, 2002.

Gibson Ivancevich., \& Donnely.Organizations, 8ed. Jakarta: Binarupa Aksara, 1996.

Spector P. E, Industrial and Organizational Psychology (Research and Practice). USA: John Wiley \& Sons, INC, 2007.

Gujarati N.Damondar, Basic Economitries Edition, Edisi ke-4, New York: McGraw-Hill Hingher Education, 2005

Hariandja E. Marihot Tua, Manajemen Sumber Daya Manusia: Pengadaan, Pengembangan, Pengkompensasian dan Peningkatan Produktivitas Pegawai Jakarta: Grasindo, 2002.

Handoko Hani, Manajemen Edisi Kedua, Yogyakarta: BPFE UGM, 2003

Irwan Z. D., Asosiasi Dosen Indoensia. Dikutip dari http://adi.Pendidikan.net/ Diakses pada tanggal 8 November 2015.

Luthans Fred, Perilaku Organisasi Edisi Sepuluh Yogyakarta: Andi, 2006.

Mangkunegara Anwar Prabu, Perencanaan dan Pengembangan Sumber Daya Manusia Bandung: Refika Aditama, 2003.

Mishra P.S., \&Mohapatra A. K. D, Relevance of Emotional Intelligence for Effective Job Performance: An Empirical Study. The Journal for Decision Makers VIKALPA, 35,1,53-61. 2010.

Mullins L. J., Management and Organisational Behaviour, 3ed. Singapore: Longman Singapore Publishers (Ptd), Ltd, 1994.

Mulyasa E., Standar Kompetensi dan Sertifikasi Guru. Bandung: PT. Remaja Rosdakarya, 2008.

Munandar A. S., Psikologi Industri dan Organisasi. Jakarta: IU-Press, 2006. 
Pusat Bahasa Departemen Pendidikan Nasional, Kamus Besar Bahasa Indonesia Jakarta: PT.Gramedia Pustaka Utama, 2008.

Ranupandojo Heidjrachman, Manajemen Personalia Edisi Kelima Yogyakarta: BPFE UGM, 2001.

Sadirman M. A., Interaksi dan Motivasi Belajar-Mengajar Jakarta: Raja Grafindo Persada, 2005.

Robbins S.P.., \& Judge A. T., Perilaku Organisasi, ed.12.Jakarta: Salemba Empat, 2008.

Sekaran Uma, Research Methods for Business Jakarta: Salemba Empat, 2006

Soetiksno A, Faktor-faktor yang Mempengaruhi Kinerja Dosen Tetap pada Perguruan Tinggi Negeri di Kota Ambon, Jurnal manajemen Akuntansi, VOL. 9. No. 2. 2009.

Sugiono, Metode Penelitian Bisnis Cetakan ke 15 Bandung: Alvabeta, 2010.

Vandeveer R.C.., \&Menefee M. L. Human Behavior in Organizations.New Jersey: Person Education, Inc, 2006.

Wijono S., Hubungan Antara Motivasi Kerja dan Personaliti dengan Prestasi Kerja di Sebuah Organisasi. Tesis.Bangi: Universiti Kebangsaan Malaysia 1997.

Wijono S., Psikologi Industri dan Organisasi: Dalam Suatu Bidang Gerak Psikologi Sumber Daya Manusia. Jakarta: Kencana Prenada Media Group, 2010.

Wirawan, Evaluasi Kinerja Sumber Daya Manusia, Jakarta: Salemba Empat, 2009. 